\title{
Immunosuppressive drugs in organ transplantation to prevent allograft rejection: Mode of action and side effects
}

\author{
Elisa Claeys, Kurt Vermeire*
}

KU Leuven Department of Microbiology, Immunology and Transplantation, Rega Institute, Laboratory of Virology and Chemotherapy, B-3000 Leuven, Belgium

\section{Article Info}

\section{Article Notes}

Received: October 17, 2019

Accepted: November 12, 2019

\section{*Correspondence:}

Dr. Kurt Vermeire, KU Leuven Department of Microbiology, Immunology and Transplantation, Rega Institute, Laboratory of Virology and Chemotherapy, B-3000 Leuven, Belgium; Email: kurt.vermeire@kuleuven.be.

(C) 2019 Vermeire K. This article is distributed under the terms of the Creative Commons Attribution 4.0 International License.

\section{Keywords:}

Organ transplantation

Allograft rejection

Immunosuppressive drugs

Side effects

\section{ABSTRACT}

Organ transplantation is a life-saving therapeutic intervention that contributes to a better quality of life in patients with end-stage organ failure. Drastically improved outcome after organ transplantation occurred with the discovery and use of immunosuppressive drugs to prevent or treat allograft rejection. Development of several immunosuppressive agents offers the option for a multidrug approach with non-overlapping toxicities. Still, the side effects of these agents can be severe, resulting in a shorter life expectancy for transplant patients compared to the general population. Therefore, the development of new immunosuppressive therapies that promote immune tolerance without the side effects observed today is needed. In this review, we will discuss the mechanism of allograft rejection as well as the mode of action and side effects of currently used immunosuppressive agents.

\section{Abbreviations}

APC, antigen-presenting cell; ATG, antithymocyte globulin; IL, interleukin; MHC, major histocompatibility complex; MMF, mycophenolate mofetil; mTOR, mammalian target of rapamycin; NFAT, nuclear factor of activated $\mathrm{T}$ cells; $\mathrm{Th}$, $\mathrm{T}$ helper; Treg, regulatory $\mathrm{T}$

\section{Introduction}

Organ transplantation is the treatment of choice for patients with end-stage organ failure, thereby increasing patient survival and improving quality of $\mathrm{life}^{1,2}$. In the first two decades after introduction of organ transplantation in the clinic, the main obstacle to success had been acute allograft rejection, a common cause of early graft loss $^{3}$. Significant progress has been made with the discovery and use of immunosuppressive drugs. With the current immunosuppressive drugs, one-year graft survival now exceeds $90 \%$ in most centers ${ }^{4}$. Unfortunately, long-term graft survival still lags behind.

A multidrug approach involving medications with different mechanisms of action and non-overlapping toxicity profiles is commonly used to lower the doses of individual drugs in order to reduce toxicity. There are three phases in immunosuppression: induction, maintenance and treatment of rejection ${ }^{5}$. The induction phase involves the use of high-intensity immunosuppression immediately after transplantation, when the risk of rejection is highest. Induction therapy can involve the use of antibodies or higher doses of medications used for maintenance therapy. The standard triple medication regimen consists of the combination of a calcineurin inhibitor, an antiproliferative agent and a corticosteroid. As immunosuppressed patients are susceptible to opportunistic infections, the treatment regimen is often supplemented with 
antimicrobial, antiviral and antifungal agents ${ }^{6}$. The side effects of immunosuppressive drugs can be severe (including an increased risk of cancer and infections), which is one of the reasons that life expectancy of transplant patients still falls short of that of the general population ${ }^{4}$. Therefore, there is a need for newer drugs that promote immune tolerance without the side effects observed with current immunosuppressive agents.

Two distinct manners exist by which transplantation tolerance can be achieved: central and peripheral tolerance ${ }^{3}$. Central tolerance includes the deletion or inactivation of alloreactive $\mathrm{T}$ cells at the time of development in the thymus. Peripheral tolerance, on the other hand, involves the deletion, inactivation or regulation of reactive immune cells after they have reached the circulation. In other words, the term 'peripheral tolerance' is applied to approaches that aim to anergize, suppress or delete alloreactive peripheral T cells. A promising approach of peripheral tolerance is the use of regulatory $\mathrm{T}$ (Treg) cells in a transplant setting?.

\section{Allograft rejection}

Rejection of the transplanted organ involves many components of the immune system including $\mathrm{CD}^{+} \mathrm{T}$ cells, CD8 ${ }^{+} \mathrm{T}$ cells, B cells, cytokines and antibodies. T cellmediated alloimmune responses occur through recognition of alloantigens presented by donor and recipient antigenpresenting dendritic cells to recipient $\mathrm{CD}^{+}$and $\mathrm{CD}^{+} \mathrm{T}^{\mathrm{T}}$ cells ${ }^{8}$. Alloreactive $\mathrm{CD}^{+} \mathrm{T}$ cells can be induced by direct recognition of allogeneic major histocompatibility complex (MHC) class II molecules or by indirect recognition of peptides of allogeneic
MHC molecules presented by self-MHC class II molecules (Figure 1). A third mechanism of allorecognition is the semidirect pathway in which recipient antigen presenting cells (APCs) can acquire intact allogeneic MHC-peptide complexes through MHC transfer ${ }^{9}$. Either way, alloreactive $\mathrm{T}$ cells get activated by a combination of alloantigen recognition through the T cell receptor/CD3 complex and a co-stimulatory signal, often an interaction between CD28 on the T cell and CD80 or CD86 on the $\mathrm{APC}^{10}$. This results in interleukin (IL)-2 secretion and $\mathrm{T}$ cell proliferation.

Several subsets of $\mathrm{CD}^{+} \mathrm{T}$ helper (Th) cells exist and are implicated in allograft rejection. Th1 cells contribute to transplant rejection via different mechanisms: (1) they produce IL-2, which promotes the proliferation of alloreactive cytotoxic $\mathrm{CD}^{+} \mathrm{T}$ cells, (2) they activate B cells to produce alloreactive antibodies and (3) they can directly cause allograft damage through Fas/Fas ligandmediated cytotoxicity ${ }^{8,11}$. Although several studies have shown that Th2 cells are involved in transplant rejection, it was suggested that Th2 cells can delay and even prevent rejection due to the production of IL-4 and IL-10, two cytokines that are able to inhibit Th1 responses ${ }^{12}$. However, there is mounting evidence that Th2 cytokines promote graft rejection by activating eosinophils ${ }^{13,14}$. Th17 cells also seem to be involved in transplant rejection through production of IL-17A and neutrophil recruitment ${ }^{15,16}$. Concerning Treg therapy in transplantation, it was shown that Th1 and Th2 cells are susceptible to suppression by Treg cells, but it is not clear whether Treg cells are capable of suppressing Th17 cells as conflicting data were published

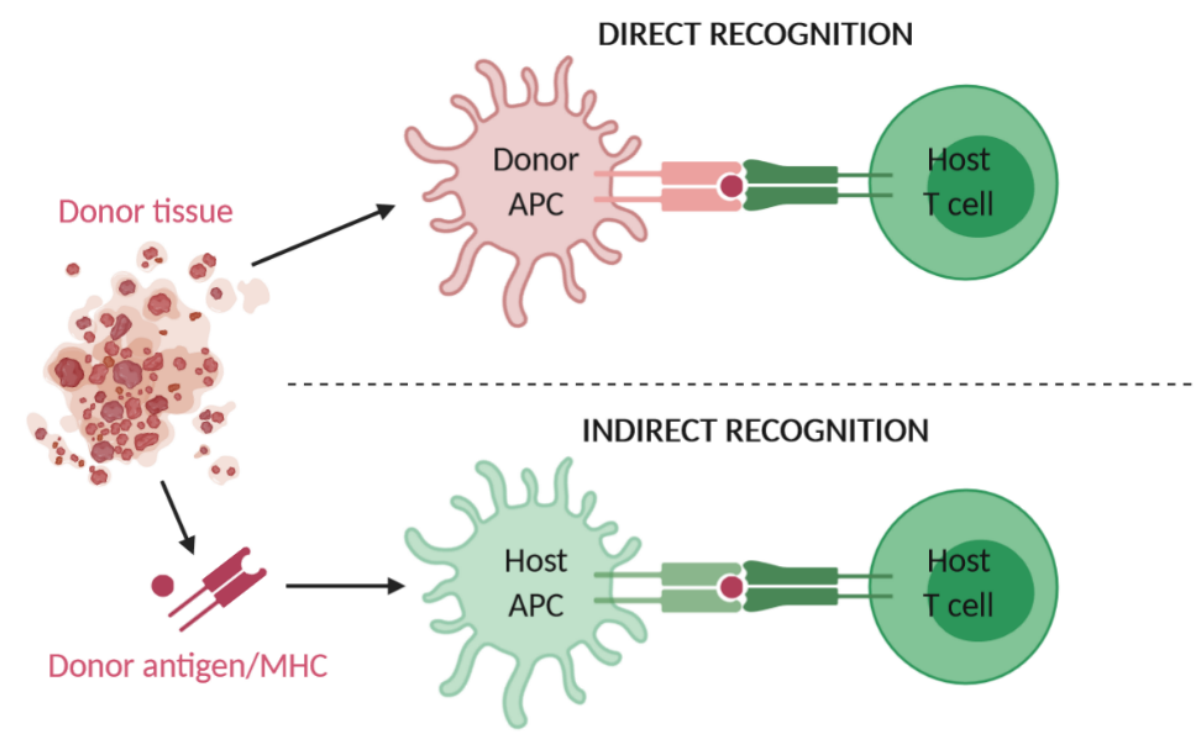

Figure 1. Mechanism of direct and indirect allograft recognition.

Alloreactive T cells can be induced by recognition of allogeneic MHC molecules on donor APCs (direct recognition) or by recognition of allogeneic peptides or $\mathrm{MHC}$ molecules processed and presented by host APCs (indirect recognition). APC, antigenpresenting cell; MHC, major histocompatibility complex. 
about this ${ }^{17,18}$. Little is known about the involvement of Th9 and Th22 in allograft rejection. There is a link between IL- 9 as well as IL-22 and transplant rejection, but many other cell types may secrete these cytokines as well ${ }^{11}$. Finally, another $\mathrm{T}$ cell subset implicated in transplant rejection worth mentioning include $\mathrm{T}$ follicular helper cells. These cells are known to provide help to B cells for alloantibody production in transplant recipients ${ }^{19}$.

\section{Immunosuppressive drugs and their side effects}

Suppression of the immune response against the transplanted tissue can be achieved through the administration of immunosuppressive drugs. Several classes of these drugs exist with different mechanisms of action and various side effects. An overview of these agents is given in Table 1.

Table 1. Immunosuppressive drugs and their mechanisms of action and side effects.

\begin{tabular}{|c|c|c|}
\hline Immunosuppressive drug & Mechanism of action & Side effects \\
\hline Antithymocyte globulin & $\begin{array}{l}\text { Blocks T cell membrane proteins, resulting in } \\
\text { T cell depletion }\end{array}$ & $\begin{array}{l}\text { Cytokine-release syndrome } \\
\text { Lymphopenia } \\
\text { Increased risk of post-transplant lymphoma }\end{array}$ \\
\hline $\begin{array}{l}\text { Alemtuzumab } \\
\text { (CAMPATH-1H) }\end{array}$ & $\begin{array}{l}\text { Directed against CD52, thereby depleting } T \\
\text { cells, B cells, NK cells and monocytes }\end{array}$ & $\begin{array}{l}\text { Cytokine-release syndrome } \\
\text { Lymphopenia } \\
\text { Autoimmune phenomena }\end{array}$ \\
\hline Rituximab & $\begin{array}{l}\text { Directed against CD20, inducing } \\
\text { B cell depletion }\end{array}$ & Infusion-related reactions \\
\hline Basiliximab & $\begin{array}{l}\text { Directed against CD25, thereby inhibiting IL-2- } \\
\text { induced T cell proliferation }\end{array}$ & Hypersensitivity reactions \\
\hline Daclizumab & $\begin{array}{l}\text { Directed against CD25, thereby inhibiting IL-2- } \\
\text { induced T cell proliferation }\end{array}$ & $\begin{array}{l}\text { Withdrawn from market due to reports of serious inflammatory brain } \\
\text { disorders }\end{array}$ \\
\hline Belatacept & $\begin{array}{l}\text { Blocks co-stimulation by binding to } C D 80 \text { and } \\
\text { CD } 86 \text { receptors on APCs and thereby prevents } \\
\text { binding to CD28 on the T cell }\end{array}$ & $\begin{array}{l}\text { Increased risk of post-transplant lymphoproliferative disease? } \\
\text { Bone marrow suppression } \\
\text { Hypertension } \\
\text { Dyslipidemia }\end{array}$ \\
\hline Azathioprine & $\begin{array}{l}\text { Inhibits purine synthesis, resulting in reduced } \\
\text { T cell proliferation }\end{array}$ & $\begin{array}{l}\text { Leukopenia and thrombocytopenia } \\
\text { Nausea and vomiting } \\
\text { Hepatotoxicity } \\
\text { Increased incidence of malignancies }\end{array}$ \\
\hline Mycophenolate mofetil & $\begin{array}{l}\text { Inhibits inosine monophosphate dehydro- } \\
\text { genase, resulting in inhibition of T and B cell } \\
\text { proliferation }\end{array}$ & $\begin{array}{l}\text { Neutropenia } \\
\text { Anorexia, abdominal pain, gastritis and diarrhea } \\
\text { Opportunistic infections } \\
\text { Teratogenic effects }\end{array}$ \\
\hline Cyclosporine & $\begin{array}{l}\text { Binds to cyclophilin and forms a complex } \\
\text { that inhibits calcineurin, leading to reduced } \\
\text { cytokine production and decreased T cell } \\
\text { proliferation }\end{array}$ & $\begin{array}{l}\text { Acute and chronic nephrotoxicity } \\
\text { Hypomagnesemia and hyperkalemia } \\
\text { Neurotoxicity } \\
\text { Increased risk of malignancies } \\
\text { Increased risk of diabetes }\end{array}$ \\
\hline Tacrolimus & $\begin{array}{l}\text { Binds to FK506-binding protein } 12 \text { and forms } \\
\text { a complex that inhibits calcineurin, leading to } \\
\text { reduced cytokine production and decreased T } \\
\text { cell proliferation }\end{array}$ & $\begin{array}{l}\text { Similar to cyclosporine except: } \\
\text { Lower incidence of hyperlipidemia, hypertension, hirsutism and gingival } \\
\text { hyperplasia } \\
\text { Higher incidence of diabetes and neurotoxicity }\end{array}$ \\
\hline Sirolimus and everolimus & $\begin{array}{l}\text { Bind to FK506-binding protein } 12 \text {, thereby } \\
\text { inhibiting } \mathrm{mTOR} \text {, resulting in decreased cyto- } \\
\text { kine-driven T cell proliferation }\end{array}$ & $\begin{array}{l}\text { Delayed wound healing } \\
\text { Leukopenia and thrombocytopenia } \\
\text { Increased risk of infections } \\
\text { Anaphylaxis and hypersensitivity reactions } \\
\text { Hyperlipidemia } \\
\text { Life-threatening pneumonitis } \\
\text { Mouth ulcers and increased mortality with sirolimus }\end{array}$ \\
\hline Corticosteroids & $\begin{array}{l}\text { Reduce the number of circulating lympho- } \\
\text { cytes, monocytes and eosinophils and inhibit } \\
\text { cytokine production }\end{array}$ & $\begin{array}{l}\text { Impaired wound healing } \\
\text { Opportunistic infections } \\
\text { Psychiatric and sleep disturbances } \\
\text { Mood changes } \\
\text { Cushing's syndrome } \\
\text { Hyperglycemia } \\
\text { Hypertension } \\
\text { Dyslipidemia } \\
\text { Osteoporosis } \\
\text { Cardiovascular side effects }\end{array}$ \\
\hline
\end{tabular}




\section{Depleting antibodies: antithymocyte globulin, Alemtuzumab and Rituximab}

Antithymocyte globulins (ATGs) are polyclonal immunoglobulins from horses or rabbits that are immunized with human thymocytes. They recognize several $\mathrm{T}$ cell membrane proteins, which results in inactivation, depletion and modulation of the homing and cytotoxic activities of $\mathrm{T}$ cells ${ }^{20,21}$. They also interfere with the function of $\mathrm{B}$ cells, dendritic cells and natural killer $\mathrm{T}$ cells ${ }^{22}$. It was even suggested that ATG would induce Treg cells ${ }^{23}$. Rabbit ATG is preferred over horse ATG because of better results in reversing and preventing rejection and improved tolerability ${ }^{24}$. Rabbit ATG is often used as an induction agent and in the case of steroidresistant rejection ${ }^{4,25}$. An important side effect of ATG is the development of cytokine-release syndrome through initial $\mathrm{T}$ cell activation, characterized by symptoms such as fever, chills, hypotension and pulmonary edema ${ }^{5}$. ATG also induces a profound, long-lasting lymphopenia and an increased risk of post-transplant lymphoma was observed $^{26,27}$.

Alemtuzumab (also known as CAMPATH-1H) is a humanized rat IgG1 monoclonal antibody directed against the CD52 cell surface antigen, expressed on T cells, B cells, natural killer cells and monocytes. It results in depletion of these cell populations and is used for induction and treatment of steroid-resistant rejection in solid organ transplants ${ }^{28-30}$. Like ATG, Alemtuzumab was suggested to induce Treg cells ${ }^{31}$. Treatment with Alemtuzumab results in profound, long-lasting lymphopenia ${ }^{32}$. Cytokine-release syndrome is also observed with Alemtuzumab, although much milder compared to $\mathrm{ATG}^{33}$, 34. Alemtuzumab was associated with autoimmune phenomena such as thyroid disease, hemolytic anemia and thrombocytopenia in patients with multiple sclerosis ${ }^{35}$.

Rituximab is a monoclonal antibody against CD20, which is present on almost all B cells except for plasma cells ${ }^{4}$. It is under study for application in antibodymediated rejection, ABO-incompatible transplantations and desensitization of human leukocyte antigen-sensitive patients ${ }^{36-38}$. Disappointing results came from a study that evaluated Rituximab as an induction agent ${ }^{39}$. Side effects include infusion-related reactions.

\section{Nondepleting antibodies: Basiliximab and Daclizumab}

Basiliximab is a chimeric human/mouse monoclonal antibody directed against the IL- 2 receptor $\alpha$-chain also known as CD25, which is expressed on activated T cells. It prevents IL-2 from binding to its receptor and thereby inhibits $\mathrm{T}$ cell proliferation and differentiation, but does not cause depletion of T cells ${ }^{5}$. Basiliximab can be used for induction therapy in prophylaxis of acute rejection. ATG is mostly used for high-risk patients, whereas Basiliximab is a good option for low-risk patients ${ }^{40}$. Few adverse effects are reported and some hypersensitivity reactions have been described ${ }^{41}$.

Daclizumab is a humanized monoclonal antibody that also targets CD25 and was indicated as induction therapy ${ }^{42}$. However, Daclizumab was also used for the treatment of multiple sclerosis, but was withdrawn from the global market in 2018 after worldwide reports of serious inflammatory brain disorders ${ }^{43}$.

\section{Belatacept}

Belatacept is a fusion protein composed of the modified extracellular domain of cytotoxic T lymphocyteassociated protein 4 (CTLA-4) and the Fc domain of human immunoglobulin IgG14. It blocks co-stimulation by binding to CD80 and CD86 receptors on APCs and thereby prevents binding to CD28 on the T cell. Belatacept is used in combination with other immunosuppressive drugs as maintenance therapy. Treatment with Belatacept holds an increased risk for the development of posttransplant lymphoproliferative disease $\mathrm{e}^{44}$. When treated with Belatacept, patients who are Epstein-Barr virusnegative are at higher risk of developing post-transplant lymphoproliferative disease ${ }^{45}$. Therefore, Belatacept should only be used in patients who are Epstein-Barr virus-positive. These observations about post-transplant lymphoproliferative disease with treatment of Belatacept were however not confirmed in a later study ${ }^{46}$. Other reported adverse effects include bone marrow suppression, hypertension and dyslipidemia ${ }^{47}$.

\section{Antiproliferative or antimetabolite agents: azathioprine and mycophenolate mofetil}

Azathioprine inhibits purine synthesis and is a prodrug that releases 6-mercaptopurine, which is incorporated into the cellular DNA, thereby halting replication and resulting in reduced $\mathrm{T}$ cell proliferation ${ }^{5}$. Azathioprine is used as maintenance therapy. The main adverse effects of azathioprine are hematological including leukopenia and thrombocytopenia, and gastrointestinal with complaints of nausea and vomiting. Hepatotoxicity and increased incidence of malignancies have also been observed.

Mycophenolate mofetil (MMF) is a prodrug that is hydrolyzed to the active immunosuppressant mycophenolic acid $^{10}$. It inhibits inosine monophosphate dehydrogenase, thereby causing inhibition of the de novo purine nucleotide synthesis. As T and B cells lack a key enzyme for the salvage pathway of guanine nucleotides, they almost exclusively rely on this de novo purine nucleotide synthesis pathway. Therefore, MMF results in inhibition of T and $B$ cell proliferation by blocking DNA synthesis, making it more selective than azathioprine. Because of this reason, MMF would be less hepatotoxic and is not associated with 
malignancies ${ }^{48}$. MMF would also decrease the recruitment of lymphocytes and monocytes into inflammatory tissue and it would upregulate CD70 expression on lymphocytes, which mediates anergy ${ }^{49,50}$. Like azathioprine, MMF is used as part of maintenance therapy and the adverse effects of MMF can be categorized as hematological including neutropenia, and gastrointestinal including anorexia, abdominal pain, gastritis and diarrhea. Opportunistic infections are also observed in patients on this drug. MMF has teratogenic effects as it increases the risk of pregnancy loss and congenital malformations ${ }^{51}$. In addition, questions raised about the influence of MMF on male fertility ${ }^{52}$. Currently, MMF is used more frequently than azathioprine, despite its higher cost and despite the fact that there is no clear evidence of superiority of MMF over azathioprine in clinical studies ${ }^{53,54}$.

\section{Calcineurin inhibitors: cyclosporine and tacrolimus}

Cyclosporine is produced by the fungus Beauveria nivea and works by binding to cyclophilin ${ }^{5}$. This complex inhibits the activity of calcineurin, a calcium-dependent phosphatase, and this results in reduced activation of nuclear factor of activated $\mathrm{T}$ cells (NFAT), leading to decreased cytokine production (including IL-2) and diminished proliferation of $\mathrm{T}$ cells. Calcineurin inhibitors are the cornerstones of maintenance immunosuppression, but a major disadvantage is their inhibitory effect on Treg cells given the dependence of these cells on IL-2 and their need for nuclear NFAT to express FOXP3 efficiently ${ }^{55}$.

Tacrolimus (FK506) is derived from the bacterium Streptomyces tsukubaensis and binds to FK506-binding protein 12 to form a complex that inhibits calcineurin. Inhibition of calcineurin occurs with greater potency compared to cyclosporine. Adverse effects of calcineurin inhibitors include acute and chronic nephrotoxicity, electrolyte abnormalities such as hypomagnesemia and hyperkalemia, neurotoxicity, increased risk of malignancy and diabetes or hyperglycemia. Tacrolimus has lower incidence of hyperlipidemia, hypertension and cosmetic problems such as hirsutism and gingival hyperplasia, but is more likely than cyclosporine to induce diabetes and neurotoxicity ${ }^{5}, 47$. Tacrolimus is currently preferable to cyclosporine due to better outcome in transplantation ${ }^{42}$, 56. Except in patients that develop diabetes, tacrolimus is replaced by cyclosporine to improve glucose metabolism ${ }^{57}$.

\section{Mammalian target of rapamycin inhibitors: sirolimus and everolimus}

Sirolimus (also known as rapamycin) is derived from the bacterium Streptomyces hygroscopicus and binds to FK506-binding protein 12. In contrast to tacrolimus, this complex does not bind to calcineurin, but instead inhibits mammalian target of rapamycin (mTOR), a serine/ threonine kinase that is important in the regulation of cell growth and proliferation ${ }^{10}$. This results in inhibition of cytokine-driven $\mathrm{T}$ cell proliferation. It was also suggested that sirolimus inhibits immunoglobulin synthesis by $B$ cells, antibody-dependent cellular cytotoxicity as well as natural killer cell activity. mTOR inhibitors are used as maintenance therapy and since delayed wound healing due to impaired response of fibroblasts to fibroblast growth factor is a major concern with these drugs, it is generally recommended not to start $\mathrm{mTOR}$ inhibitors immediately after transplant surgery. mTOR inhibitors are often used in patients experiencing calcineurin inhibitor-mediated nephrotoxicity ${ }^{58,59}$. Mouth ulcers are often observed in patients treated with sirolimus and can occasionally result in discontinuation of treatment ${ }^{60}$.

Everolimus is a derivative of sirolimus with improved oral bioavailability and shares its mechanism of action ${ }^{33}$. Both sirolimus and everolimus are associated with an increased risk of infections, hyperlipidemia as well as leukopenia and thrombocytopenia. Anaphylaxis and hypersensitivity reactions have been observed too. mTOR inhibitors are less nephrotoxic and diabetogenic compared to calcineurin inhibitors, but they can cause life-threatening pneumonitis ${ }^{61}$. In addition, sirolimus was associated with increased mortality ${ }^{62}$. However, mTOR inhibitors appear to have some anti-tumor properties, so are the treatment of choice in transplant patients in whom cutaneous squamous-cell carcinomas develop or in whom post-transplant Kaposi's sarcoma develops ${ }^{63,64}$.

\section{Corticosteroids}

Corticosteroids exhibit anti-inflammatory and immunosuppressive activity through three mechanisms: direct genomic effects, indirect genomic effects and nongenomic mechanisms ${ }^{4,65}$. Direct genomic effects occur when corticosteroids together with their receptor move to the nucleus and directly affect transcription. This, for example, induces annexin I and mitogen-activated protein kinase, resulting in inhibition of prostaglandin synthesis and in reduced inflammation. Indirect genomic effects take place when corticosteroids and their receptors interact with other transcription factors. This among other things results in inhibition of nuclear factor kappa-light-chain-enhancer of activated B cells (NF- $\kappa B$ ), which also leads to inhibited prostaglandin synthesis. In general, genomic effects result in the upregulation of transcription of anti-inflammatory genes (transactivation) or in downregulation of transcription of inflammatory genes (transrepression) ${ }^{66}$. Nongenomic effects occur very rapidly and include the activation of endothelial nitric oxide synthetase, which appears to protect against ischemia and reperfusion-induced injury in mice ${ }^{67}$. The net result of these pathways is a dramatic reduction in circulating lymphocytes, monocytes and eosinophils due to redistribution, inhibition of cytokines and induction of 
apoptosis $^{68}$. Corticosteroids are used both for induction and maintenance therapy, but long-term use is associated with several side effects including opportunistic infections, Cushing's syndrome, psychiatric and sleep disturbances, mood changes, hyperglycemia, hypertension, dyslipidemia, impaired wound healing and osteoporosis. Corticosteroids also play a role in cardiovascular events after successful transplantation ${ }^{69}$.

\section{Conclusions}

The outcome of organ transplantation has majorly improved since the development of immunosuppressive drugs. Still, the side effects of these drugs can be severe, resulting in a shorter life expectancy for transplant patients compared to the general population. Thus, the development of new therapies that can induce immune tolerance in combination with no or limited side effects is needed. Fortunately, several novel strategies of immune tolerance induction are getting explored. For example, therapy based on Treg cells or chimeric antigen receptor (CAR) Treg cells is very promising in the transplantation field $^{70}$. Additionally, novel immunosuppressive biologics (e.g. anti-IL-6) ${ }^{71}$ or kinase inhibitors (e.g. anti-JAK3) ${ }^{72}$ are emerging to prevent or treat allograft rejection after transplantation.

\section{Acknowledgements}

This work was partly supported by the KU Leuven grant no. PF/10/018. The figure was created using BioRender.

\section{References}

1. Morris PJ. Transplantation--a medical miracle of the 20th century. $\mathrm{N}$ Engl J Med. 2004; 351(26): 2678-80.

2. Sayegh MH, Carpenter CB. Transplantation 50 years later--progress, challenges, and promises. N Engl J Med. 2004; 351(26): 2761-6.

3. Adler SH, Turka LA. Immunotherapy as a means to induce transplantation tolerance. Curr Opin Immunol. 2002; 14(5): 660-5.

4. van Sandwijk MS, Bemelman FJ, Ten Berge IJ. Immunosuppressive drugs after solid organ transplantation. Neth J Med. 2013; 71(6): 281-9.

5. Enderby C, Keller CA. An overview of immunosuppression in solid organ transplantation. Am J Manag Care. 2015; 21(1 Suppl): s12-23.

6. Fishman JA. Infection in solid-organ transplant recipients. N Engl J Med. 2007; 357(25): 2601-14.

7. van der Net JB, Bushell A, Wood KJ, et al. Regulatory T cells: first steps of clinical application in solid organ transplantation. Transpl Int. 2016; 29(1): 3-11.

8. Jiang S, Herrera 0, Lechler RI. New spectrum of allorecognition pathways: implications for graft rejection and transplantation tolerance. Curr Opin Immunol. 2004; 16(5): 550-7.

9. Herrera OB, Golshayan D, Tibbott R, et al. A novel pathway of alloantigen presentation by dendritic cells. J Immunol. 2004; 173(8): 4828-37.

10. Coelho T, Tredger M, Dhawan A. Current status of immunosuppressive agents for solid organ transplantation in children. Pediatr Transplant. 2012; 16(2): 106-22.
11. Liu Z, Fan H, Jiang S. CD4(+) T-cell subsets in transplantation. Immunol Rev. 2013; 252(1): 183-91.

12. Waaga AM, Gasser M, Kist-van Holthe JE, et al. Regulatory functions of self-restricted MHC class II allopeptide-specific Th2 clones in vivo. J Clin Invest. 2001; 107(7): 909-16.

13. Nocera A, Tagliamacco A, De Palma R, et al. Cytokine mRNA expression in chronically rejected human renal allografts. Clin Transplant. 2004; 18(5): 564-70.

14. Goldman M, Le Moine A, Braun M, et al. A role for eosinophils in transplant rejection. Trends Immunol. 2001; 22(5): 247-51.

15. Gorbacheva V, Fan R, Li X, et al. Interleukin-17 promotes early allograft inflammation. Am J Pathol. 2010; 177(3): 1265-73.

16. Fan L, Benson HL, Vittal R, et al. Neutralizing IL-17 prevents obliterative bronchiolitis in murine orthotopic lung transplantation. Am J Transplant. 2011; 11(5): 911-22.

17. Benghiat FS, Craciun L, De Wilde V, et al. IL-17 production elicited by allo-major histocompatibility complex class II recognition depends on CD25posCD4pos T cells. Transplantation. 2008; 85(7): 943-9.

18. Hester J, Mills N, Shankar S, et al. Th17 cells in alemtuzumab-treated patients: the effect of long-term maintenance immunosuppressive therapy. Transplantation. 2011; 91(7): 744-50.

19. La Muraglia II GM, Wagener ME, Ford ML, et al. Circulating T follicular helper cells are a biomarker of humoral alloreactivity and predict donor-specific antibody formation after transplantation. Am J Transplant. 2019.

20. Bonnefoy-Berard N, Vincent C, Revillard JP. Antibodies against functional leukocyte surface molecules in polyclonal antilymphocyte and antithymocyte globulins. Transplantation. 1991; 51(3): 669-73.

21. Bonnefoy-Berard N, Verrier B, Vincent C, et al. Inhibition of CD25 (IL-2R alpha) expression and T-cell proliferation by polyclonal antithymocyte globulins. Immunology. 1992; 77(1): 61-7.

22. Brayman K. New Insights Into the Mechanisms of Action of Thymoglobulin. Transplantation. 2007; 84(11S): S3-S4.

23. Lopez M, Clarkson MR, Albin M, et al. A novel mechanism of action for anti-thymocyte globulin: induction of CD4+CD25+Foxp3+ regulatory T cells. J Am Soc Nephrol. 2006; 17(10): 2844-53.

24. Gaber AO, First MR, Tesi RJ, et al. Results of the double-blind, randomized, multicenter, phase III clinical trial of Thymoglobulin versus Atgam in the treatment of acute graft rejection episodes after renal transplantation. Transplantation. 1998; 66(1): 29-37.

25. Halloran PF. Immunosuppressive drugs for kidney transplantation. $\mathrm{N}$ Engl J Med. 2004; 351(26): 2715-29.

26. Havenith SH, Remmerswaal EB, Bemelman FJ, et al. Rapid T cell repopulation after rabbit anti-thymocyte globulin (rATG) treatment is driven mainly by cytomegalovirus. Clin Exp Immunol. 2012; 169(3): 292-301.

27. Opelz G, Dohler B. Lymphomas after solid organ transplantation: a collaborative transplant study report. Am J Transplant. 2004; 4(2): 222-30.

28. Hanaway MJ, Woodle ES, Mulgaonkar S, et al. Alemtuzumab induction in renal transplantation. N Engl J Med. 2011; 364(20): 1909-19.

29. van den Hoogen MW, Hesselink DA, van Son WJ, et al. Treatment of steroid-resistant acute renal allograft rejection with alemtuzumab. Am J Transplant. 2013; 13(1): 192-6.

30. Woodside KJ, Lick SD. Alemtuzumab (Campath $1 \mathrm{H}$ ) as successful salvage therapy for recurrent steroid-resistant heart transplant rejection. J Heart Lung Transplant. 2007; 26(7): 750-2.

31. Bloom DD, Chang Z, Fechner JH, et al. CD4+ CD25+ FOXP3+ regulatory $\mathrm{T}$ cells increase de novo in kidney transplant patients after 
immunodepletion with Campath-1H. Am J Transplant. 2008; 8(4): 793-802.

32. Isaacs JD, Greer S, Sharma S, et al. Morbidity and mortality in rheumatoid arthritis patients with prolonged and profound therapyinduced lymphopenia. Arthritis Rheum. 2001; 44(9): 1998-2008.

33. Watson CJ, Dark JH. Organ transplantation: historical perspective and current practice. Br J Anaesth. 2012; 108 Suppl 1: i29-42.

34. Hale G. The CD52 antigen and development of the CAMPATH antibodies. Cytotherapy. 2001; 3(3): 137-43.

35. Cossburn M, Pace AA, Jones J, et al. Autoimmune disease after alemtuzumab treatment for multiple sclerosis in a multicenter cohort. Neurology. 2011; 77(6): 573-9.

36. Roberts DM, Jiang SH, Chadban SJ. The treatment of acute antibodymediated rejection in kidney transplant recipients-a systematic review. Transplantation. 2012; 94(8): 775-83.

37. Fuchinoue S, Ishii Y, Sawada T, et al. The 5-year outcome of ABOincompatible kidney transplantation with rituximab induction. Transplantation. 2011; 91(8): 853-7.

38. Vo AA, Peng A, Toyoda M, et al. Use of intravenous immune globulin and rituximab for desensitization of highly HLA-sensitized patients awaiting kidney transplantation. Transplantation. 2010; 89(9): 1095102.

39. Tyden G, Ekberg H, Tufveson G, et al. A randomized, double-blind, placebo-controlled study of single dose rituximab as induction in renal transplantation: a 3-year follow-up. Transplantation. 2012; 94(3): e21-2.

40. Knight RJ, Kerman RH, Schoenberg L, et al. The selective use of basiliximab versus thymoglobulin in combination with sirolimus for cadaveric renal transplant recipients at low risk versus high risk for delayed graft function. Transplantation. 2004; 78(6): 904-10.

41. Chapman TM, Keating GM. Basiliximab: a review of its use as induction therapy in renal transplantation. Drugs. 2003; 63(24): 2803-35.

42. Ekberg H, Tedesco-Silva H, Demirbas A, et al. Reduced exposure to calcineurin inhibitors in renal transplantation. N Engl J Med. 2007; 357(25): 2562-75.

43. Daclizumab withdrawn from the market worldwide. Drug Ther Bull. 2018; 56(4): 38.

44. Martin ST, Powell JT, Patel M, et al. Risk of posttransplant lymphoproliferative disorder associated with use of belatacept. Am J Health Syst Pharm. 2013; 70(22): 1977-83.

45. Martin ST, Tichy EM, Gabardi S. Belatacept: a novel biologic for maintenance immunosuppression after renal transplantation. Pharmacotherapy. 2011; 31(4): 394-407.

46. Vincenti F, Rostaing L, Grinyo J, et al. Belatacept and Long-Term Outcomes in Kidney Transplantation. N Engl J Med. 2016; 374(4): 333-43.

47. Marcen R. Immunosuppressive drugs in kidney transplantation: impact on patient survival, and incidence of cardiovascular disease, malignancy and infection. Drugs. 2009; 69(16): 2227-43.

48. Guba M, Graeb C, Jauch KW, et al. Pro- and anti-cancer effects of immunosuppressive agents used in organ transplantation. Transplantation. 2004; 77(12): 1777-82.

49. Ritter ML, Pirofski L. Mycophenolate mofetil: effects on cellular immune subsets, infectious complications, and antimicrobial activity. Transpl Infect Dis. 2009; 11(4): 290-7.

50. He X, Smeets RL, Koenen HJ, et al. Mycophenolic acid-mediated suppression of human CD4+ T cells: more than mere guanine nucleotide deprivation. Am J Transplant. 2011; 11(3): 439-49.

51. Hoeltzenbein $M$, Elefant $E$, Vial $T$, et al. Teratogenicity of mycophenolate confirmed in a prospective study of the European Network of Teratology Information Services. Am J Med Genet A. 2012; 158a(3): 588-96.

52. Kuypers DR, Van Mieghem T, Meijers B, et al. Updated Manufacturer and European Medicines Agency Recommendations on the Use of Mycophenolate Acid: Balancing the Risks for Male Allograft Recipients. Transplantation. 2016; 100(9): e50-1.

53. Remuzzi G, Lesti M, Gotti E, et al. Mycophenolate mofetil versus azathioprine for prevention of acute rejection in renal transplantation (MYSS): a randomised trial. Lancet. 2004; 364(9433): 503-12.

54. Remuzzi G, Cravedi P, Costantini M, et al. Mycophenolate mofetil versus azathioprine for prevention of chronic allograft dysfunction in renal transplantation: the MYSS follow-up randomized, controlled clinical trial. J Am Soc Nephrol. 2007; 18(6): 1973-85.

55. Whitehouse G, Gray E, Mastoridis S, et al. IL-2 therapy restores regulatory T-cell dysfunction induced by calcineurin inhibitors. Proc Natl Acad Sci U S A. 2017; 114(27): 7083-8.

56. Webster A, Woodroffe RC, Taylor RS, et al. Tacrolimus versus cyclosporin as primary immunosuppression for kidney transplant recipients. Cochrane Database Syst Rev. 2005(4): Cd003961.

57. Wissing KM, Abramowicz D, Weekers L, et al. Prospective randomized study of conversion from tacrolimus to cyclosporine A to improve glucose metabolism in patients with posttransplant diabetes mellitus after renal transplantation. Am J Transplant. 2018; 18(7): 1726-34.

58. Schena FP, Pascoe MD, Alberu J, et al. Conversion from calcineurin inhibitors to sirolimus maintenance therapy in renal allograft recipients: 24-month efficacy and safety results from the CONVERT trial. Transplantation. 2009; 87(2): 233-42.

59. Budde K, Becker T, Arns W, et al. Everolimus-based, calcineurininhibitor-free regimen in recipients of de-novo kidney transplants: an open-label, randomised, controlled trial. Lancet. 2011; 377(9768): 837-47.

60. Fricain JC, Cellerie K, Sibaud V, et al. [Oral ulcers in kidney allograft recipients treated with sirolimus]. Ann Dermatol Venereol. 2008; 135(11): 737-41.

61. Morelon E, Stern M, Kreis H. Interstitial pneumonitis associated with sirolimus therapy in renal-transplant recipients. N Engl J Med. 2000; 343(3): 225-6.

62. Knoll GA, Kokolo MB, Mallick R, et al. Effect of sirolimus on malignancy and survival after kidney transplantation: systematic review and meta-analysis of individual patient data. Bmj. 2014; 349: g6679.

63. Euvrard S, Morelon E, Rostaing L, et al. Sirolimus and secondary skincancer prevention in kidney transplantation. N Engl J Med. 2012; 367(4): 329-39.

64. Campistol JM, Gutierrez-Dalmau A, Torregrosa JV. Conversion to sirolimus: a successful treatment for posttransplantation Kaposi's sarcoma. Transplantation. 2004; 77(5): 760-2.

65. Rhen T, Cidlowski JA. Antiinflammatory action of glucocorticoids-new mechanisms for old drugs. N Engl J Med. 2005; 353(16): 1711-23.

66. Liu D, Ahmet A, Ward L, et al. A practical guide to the monitoring and management of the complications of systemic corticosteroid therapy. Allergy Asthma Clin Immunol. 2013; 9(1): 30.

67. Hafezi-Moghadam A, Simoncini T, Yang Z, et al. Acute cardiovascular protective effects of corticosteroids are mediated by nontranscriptional activation of endothelial nitric oxide synthase. Nat Med. 2002; 8(5): 473-9.

68. Lanza L, Scudeletti M, Puppo F, et al. Prednisone increases apoptosis in in vitro activated human peripheral blood T lymphocytes. Clin Exp Immunol. 1996; 103(3): 482-90.

69. Vanrenterghem YF, Claes K, Montagnino G, et al. Risk factors for 
cardiovascular events after successful renal transplantation. Transplantation. 2008; 85(2): 209-16.

70. Zhang Q, Lu W, Liang CL, et al. Chimeric Antigen Receptor (CAR) Treg: A Promising Approach to Inducing Immunological Tolerance. Front Immunol. 2018; 9: 2359.

71. Solhjou Z, Uehara M, Bahmani B, et al. Novel Application of Localized
Nanodelivery of Anti-Interleukin-6 Protects Organ Transplant From Ischemia-Reperfusion Injuries. Am J Transplant. 2017; 17(9): 2326-37.

72. Busque S, Leventhal J, Brennan DC, et al. Calcineurin-inhibitor-free immunosuppression based on the JAK inhibitor CP-690,550: a pilot study in de novo kidney allograft recipients. Am J Transplant. 2009; 9(8): 1936-45. 